\title{
Promotion of Renewables and the Challenges in the Water Sector
}

\section{Karolis Gudas / Simona Weber ${ }^{1}$}

Abstract

This paper briefly outlines the interlinkages between the water protection objective and the decarbonisation objective. It concludes that low-carbon renewable electricity policy scenario may have negative externalities on the water body under the existing regulatory framework in the EU. The analysis is mainly dealt within the framework of the European Union's Renewable Energy Directive of 2009 (RES Directive).

NCCR TRADE WORKING PAPERS are preliminary documents posted on the NCCR Trade Regulation website (<www.nccr-trade.org>)and widely circulated to stimulate discussion and critical comment. These papers have not been formally edited. Citations should refer to an "NCCR Trade Working Paper", with appropriate reference made to the author(s).

\footnotetext{
${ }^{1}$ Karolis Gudas is a PhD Student at the World Trade Institute, University of Bern. Simona Weber is a PhD Student at the Institute for European and International Economic Law, University of Bern. She is currently working as an Attorney in the Legal Department of the Federal Office for the Environment (FOEN).
} 


\section{Introduction}

The European Union (EU) has set the goal of $20 \%$ of the energy consumption to be from renewable energy sources (RES) by 2020. For this purpose Member States have to achieve individual national targets. ${ }^{2}$ The measures taken to meet the targets and the general course of the national renewable energy policies has to be specified in national renewable energy action plans, which are in line with the Renewable Energy Directive of 2009 (RES Directive).

The RES Directive stipulates the reasons for the promotion of renewables. Primarily, these are security and diversification of energy supply, environmental protection, social and economic cohesion, technological development and innovation ${ }^{3}$. Among the major drivers of the RES deployment is, arguably, climate change mitigation. It has been used as justification of electricity trade distortions in relation to implementation of RES support schemes already several times ${ }^{4}$.

This paper discusses the tension existing between the climate change mitigation policy objective and other environmental objectives. In particular, it examines the regulatory shortcomings arising from the implementation of the RES Directive, by outlining challenges on the water-energy nexus.

\section{General Overview}

The RES Directive stipulates forms of renewable energies, the promotion of which constitutes important parts of the package of measures needed to reduce greenhouse gas emissions. ${ }^{5}$ These forms namely include wind, solar, aerothermal, geothermal, hydrothermal and ocean energy, hydropower, biomass, landfill gas, sewage treatment plant gas and biogases. ${ }^{6}$ The use of any of these forms of renewable energy may be promoted by any instrument, scheme or mechanism at the discretion of the Member State, for instance, by increasing the price at which it can be sold, or increasing the volume of such

\footnotetext{
2 'RES Directive' Art 3

3 ‘RES Directive’ Recitals [1], [8], [15], [19], etc.

4 Since the 2003 PreussenElektra case, the Court of Justice of the European Union (CJEU) has been consistent in arguing that the use of renewable energy sources for the production of electricity ... is useful for the protection of the environment inasmuch as it contributes to the reduction in greenhouse gas emissions...' See: Sybe de Vries, 'Case C-379/98 PreussenElektra AG v Schleswag AG', para 73, Court of Justice of the European Union; 'Case C-573/12 Ålands Vindkraft AB v Energimyndigheten', para 78, Court of Justice of the European Union; 'Cases C-204/12 to C-208/12 Essent Belgium NV v Vlaamse Reguleringsinstantie', para 91, Court of Justice of the European Union

5 ‘RES Directive' Recital 1

${ }^{6}$ Art. 2a of the RES Directive
} 
energy purchased7. There are no EU-wide rules governing implementation of the RES support schemes 8 , with the exception of the recent 'Guidelines on State Aid for Environmental Protection and Energy 2014-2020' of the European Commission (see below).

However, the European Commission in the 'Guidelines on State aid for environmental protection and energy 2014-2020' outlined only hydropower as technology, which may contribute towards the climate change mitigation objective, but negatively affect the water-body status. ${ }^{9}$ It has disregarded the challenges on the water-energy nexus not only with respect to renewables promotion, but as well as other technologies which contribute towards climate change mitigation objective and have a negative effect on the water-body status. These include the carbon capture and storage technology.

\section{Renewables' promotion and climate change mitigation objective}

A transition to low-carbon energy requires renewables promotion, but it may undermine the objectives pursued in the water sector. In particular, promotion of certain renewables may place significant water constrains. Growing water constraints may threaten the feasibility of energy investments and adversely impact other sectors depending on energy and water, such as the agricultural one. ${ }^{10}$

On one hand, few forms of renewables, which are eligible to benefit from the EU's Member States support schemes, may require significant water withdrawals and consumption: ${ }^{11}$

1. Concentrating solar power (CSP) requires water from 2'800 - 3'500 liter/MWh depending on the technology used. ${ }^{12}$ This technology can

\footnotetext{
7 Art. 2k of the RES Directive

8 'Case C-573/12 Ålands Vindkraft AB v Energimyndigheten' , para 62

9 European Commission, 'Guidelines on State aid for environmental protection and energy 2014-2020', June 28, 2014 para 117

10 International Energy Agency and Organisation for Economic Co-operation and Development, World energy outlook, 2012 49; Brahma Chellaney, Water, Peace, and War: Confronting the Global Water Crisis (Auflage: New. Rowman \& Littlefield 2013) 101; Michelle T H van Vliet, Stefan Vögele, and Dirk Rübbelke, 'Water constraints on European power supply under climate change: impacts on electricity prices' (2013) 8 Environmental Research Letters 035010, 6

11 See International Energy Agency and Organisation for Economic Co-operation and Development, World energy outlook, 2012 (OECD/IEA 2012) 514 -517

12 Dominic Waughray (ed), Water security the water-food-energy-climate nexus: the World Economic Forum water initiative (Island Press 2011) 509-510; World Economic Forum, Thirsty Energy: Water and Energy in The 21st Century, 2008 21; U.S. Department on Energy, 'Energy Demands on Water Resources: Report to the Congress on the Interdependency of Energy and Water', December 200665 Table B-1
} 
use five times more water than a gas-fired power plant and the double of a nuclear power plant. ${ }^{13}$

2. Biofuels produced from corn or soy can use 9'000-270'000 liters/GJ depending on the irrigation needs. Therefore, grain and oilseed crops grown for biofuels can be much more water-intensive than the petroleum, which is estimated to use 3 - 9'000 liters/GJ for mining and processing of the raw material. ${ }^{14}$

3. The water withdrawals and consumption for geothermal power production range widely and can go up to more than $10^{\prime} 000$ liter/MWh depending on the production technique and the well depth. ${ }^{15}$

4. The water consumption from hydropower is caused by evaporation loss, which is on average $17^{\prime} 000$ liters per MWh, depending highly on the local climate and dimension of the reservoir. ${ }^{16}$

On the other hand, low-carbon renewable electricity policy option could be water-neutral one. Non-thermal renewables such as solar photovoltaic (PV) and wind energy convert sun and wind directly into electricity. Neither wind energy, nor solar PV are water intensive technologies. ${ }^{17}$

\section{The Response of International Organizations to Water Challenges}

The Department of Energy (DoE) of the United States was the first one to outline threats on the national energy production that arise from the limited water supplies ${ }^{18}$. The report was distributed in 2006.19 International organizations, namely the European Environment Agency ${ }^{20}$, International

\footnotetext{
13 UN Water, The United Nations World Water Development Report 2014 - Water and Energy, 201440

14 Waughray, Water security the water-food-energy-climate nexus 47

15 International Energy Agency and Organisation for Economic Co-operation and Development, World energy outlook, 2012 510; UN Water, The United Nations World Water Development Report 2014 - Water and Energy 41; United Nation - Economic Commission for Europe, 'Water-food-energy-ecosystem nexus', March 27, 2015<http://www.unece.org/env/water/nexus>accessed 27 March 2015

16 World Bank, 'Thirsty Energy: Securing Energy in a Water-Constrained World', 2013 21-22

17 International Energy Agency and Organisation for Economic Co-operation and Development, World energy outlook, 2012509 - 510

18 Karen Hussey and Jamie Pittock, 'The Energy-Water Nexus: Managing the Links between Energy and Water for a Sustainable Future' (2012) 17 Ecology and Society, 3

${ }^{19}$ Karen Hussey and Jamie Pittock, 'The Energy-Water Nexus: Managing the Links between Energy and Water for a Sustainable Future' (2012) 17 Ecology and Society, 3

20 Beate Werner and European Environment Agency, European waters: current status and future challenges: synthesis (Publications Office 2012) 27,33-34; European Environment Agency., Water resources across Europe: confronting water scarcity and drought. (European Environment Agency 2009) 25; European Environment Agency, Climate change, impacts and vulnerability in Europe 2012: an indicator-based report (Off. for Official Publ. of the Europ. Union 2012) 201; Wouter Vanneuville, Beate Werner, and European
} 
Energy Agency, World Bank and United Nations, have corresponded to water concerns only in 2011-2013.

The International Energy Agency (IEA) provided an overview of water requirements imposed on the energy production, using different energy policy scenarios. ${ }^{21}$ It concluded that the availability of water for energy production will become more constrained in future due to the population growth, global economic growth and climate change. Based on this, the IEA suggested to rely more on energy technologies that do not use much water, and to deploy more advanced and water-saving cooling systems. ${ }^{22}$

Similarly, the World Bank and the United Nations reviewed some of the water-related challenges in the energy sector. The World Bank examined the water requirements for electricity generation, and outlined the need for an integrated energy-water modelling framework. It concluded that policymakers need to consider whether water supply will be sufficient for the cooling of existing and planned power plants. ${ }^{23}$ The United Nations highlighted that policies adopted in response to climate change, which mitigate greenhouse gas emissions through hydropower or biofuels, may place great constrains on water resources. ${ }^{24}$

\section{Conclusion}

The low-carbon renewable electricity policy scenario could be less water intensive one. However, this is not insured under the existing regulatory framework in the EU. In particular, the production of biopower, geothermal, concentrating solar power and hydropower can use a lot of water and have adverse effects on the aquatic ecosystem. The impact on water should be directly taken into account in renewable energy promotion schemes in order to achieve the policy objectives in the field of environmental protection, and bring the coherence between the different policy objectives.

Environment Agency, Water resources in Europe in the context of vulnerability: EEA 2012 state of water assessment. (Publications Office 2012) 54

${ }^{21}$ International Energy Agency and Organisation for Economic Co-operation and Development, World energy outlook, 2012 514-528

22 International Energy Agency and Organisation for Economic Co-operation and Development, World energy outlook, $2012527-528$

23 World Bank, 'Thirsty Energy: Securing Energy in a Water-Constrained World' 17-22

24 The United Nations World Water Development Report 2014 - Facing the Challenges (Unesco 2014) 103 and 105 


\section{BIBLIOGRAPHY}

Chellaney, Brahma, Water, Peace, and War: Confronting the Global Water Crisis (Auflage: New. Rowman \& Littlefield 2013).

Council of European Energy Regulators, 'Status Review of Renewable and Energy Efficiency Support Schemes in Europe', June 25, 2013, 53.

European Parliament, 'Council Directive (EC) 2009/28 on the promotion of the use of energy from renewable sources', 2009.

European Commission, 'Guidelines on State aid for environmental protection and energy 2014-2020', June 28, 2014.

Farmer, Andrew, Thomas Dworak, Sarah Bogaert, Maria Berglund, Tony Zamparutti, Eduard Interwies, Pierre Strosser, and others, 'Service contract to support the impact assessment of the blueprint to safeguard Europe's waters' [2012] Assessment of Policy Options for the Blueprint. Final Report.

International Energy Agency, and Organisation for Economic Co-operation and Development, World energy outlook, 2012 (OECD/IEA 2012).

Rio Carrillo, Anna Mercè, and Christoph Frei, 'Water: A key resource in energy production' (2009) 37 Energy Policy, 4303.

United Nation - Economic Commission for Europe, 'Water-food-energyecosystem nexus', March 27, 2015.

UN Water, The United Nations World Water Development Report 2014 - Water and Energy, 2014.

U.S. Department on Energy, 'Energy Demands on Water Resources: Report to the Congress on the Interdependency of Energy and Water', December 2006.

Vliet, Michelle T H van, Stefan Vögele, and Dirk Rübbelke, 'Water constraints on European power supply under climate change: impacts on electricity prices' (2013) 8 Environmental Research Letters, 035010.

Vries, Sybe de, 'Case C-379/98 PreussenElektra AG v Schleswag AG', p. , Court of Justice of the European Union.

Waughray, Dominic, ed., Water security the water-food-energy-climate nexus: the World Economic Forum water initiative (Island Press 2011). 
World Bank, 'Thirsty Energy: Securing Energy in a Water-Constrained World', 2013.

World Enconomic Forum, Thirsty Energy: Water and Energy in The 21st Century, 2008.

'Consolidated Version of the Treaty on the Functioning of the European Union', 2012.

The United Nations World Water Development Report 2014 - Facing the Challenges (Unesco 2014).

‘Europe's water resources “under pressure” - BBC News', 2012.

'EU carbon target threatened by biomass "insanity" | Environment | The Guardian', 2012. 